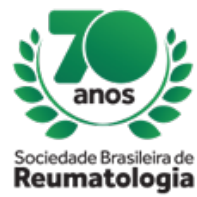

\title{
QUALITY OF LIFE OF PATIENTS WITH FIBROMYALGIA IN MULTIDISCIPLINARY EDUCATIONAL GROUP
}

Thais Menezes Rabelo De Jesus Santana (UNIVERSIDADE FEDERAL DE SERGIPE, ARACAJU, SE, Brasil), Monica Valeria Siqueira Santana De Vechi (UNIVERSIDADE FEDERAL DE SERGIPE , ARACAJU, SE, Brasil), Thiago Reis De Santana (UNIVERSIDADE FEDERAL DE SERGIPE , ARACAJU, SE, Brasil), Luiza Todt Cardoso De Faro (UNIVERSIDADE FEDERAL DE SERGIPE , ARACAJU, SE, Brasil), Giovana Dutra Saquy (UNIVERSIDADE FEDERAL DE SERGIPE , ARACAJU, SE, Brasil), Lina Oliveira De Carvalho (UNIVERSIDADE FEDERAL DE SERGIPE , ARACAJU, SE, Brasil), Blenda Hilíria De Sousa Dias (UNIVERSIDADE FEDERAL DE SERGIPE , ARACAJU, SE, Brasil), Regina Adalva De Lucena Couto Ocea (UNIVERSIDADE FEDERAL DE SERGIPE , ARACAJU, SE, Brasil), Jose Caetano Macieira (UNIVERSIDADE FEDERAL DE SERGIPE , ARACAJU, SE, Brasil)

\section{BACKGROUND}

Fibromyalgia is a rheumatic syndrome often associated with chronic diffuse pain, fatigue, unrefreshing sleep, morning stiffness, anxiety and depression. Daily living with such symptoms negatively affects people's quality of life. The need for lifestyle modification to improve the overall picture requires the follow-up of a multi-disciplinary team. Thus, the present study aims to evaluate the quality of life of patients with fibromyalgia.

\section{MATERIALS AND METHODS}

This is a cohort with 40 patients during eight months through monthly meetings in a multidisciplinary educational group (lectures and orientations of psychologist, occupational therapist, physiotherapist, speech therapist, nurse, physical educator and physician). To evaluate the quality of life (QOL), a specific instrument was used: the Fibromyalgia Impact Questionnaire (FIQ), applied before and after the meetings. A descriptive analysis was performed, with frequency and percentage calculations for the qualitative variables and measures of central tendency (mean) and variability (standard deviation (SD)) for the quantitative variables.

\section{RESULTS}

All patients were female. The mean age was 49.52 years $S D \pm 11.43$. The majority of the $62.5 \%$ (25) were married and $77.5 \%$ (31), with an average monthly income of $R \$ 1717.58$ SD \pm 1237.9 . The mean number of years of study (schooling) observed was 10.55 years $\mathrm{SD} \pm 5.32$. After the participation in the educational group, $77.5 \%$ (31) of the patients presented a decrease in the FIQ score, the general mean of the FIQ being before the educational program 73,44, and, after eight months of meetings, 58,94. It was observed that $22.5 \%$ (9 patients) presented worsening or did not improve after participating in the educational program, among these, six patients were considered as non-adherent (participated in less than $50 \%$ of the educational group meetings). The FIQ questions were also analyzed separately and improvement was observed for most participants in relation to six of the FIQ's 10 questions: Functional capacity (67.50\%), Ability to work (52.50\%), Pain (57, 50\%), Rigidity (65\%), Anxiety (62.50\%), Depression (55\%).

\section{CONCLUSION}

It was concluded that the participation of patients with fibromyalgia in a multidisciplinary educational program may contribute to a reduction in the FIQ score, which may reflect an improvement in the QOL of these patients. 